\title{
Fatal pulmonary parafilaroidiasis in a free-ranging subantarctic fur seal (Arctocephalus tropicalis) coinfected with two gammaherpesviruses and Sarcocystis sp.
}

\author{
Parafilaroidose pulmonar fatal em um lobo-marinho-subantártico (Arctocephalus tropicalis) de vida livre \\ coinfectado com dois gammaherpesvírus e Sarcocystis sp. \\ Laura Reisfeld ${ }^{1,2^{*}}$ (1); Carlos Sacristán ${ }^{1}$; Angélica María Sánchez-Sarmiento ${ }^{1}$; \\ Samira Costa-Silva ${ }^{1}$; Josué Díaz-Delgado ${ }^{1}$; Kátia Regina Groch ${ }^{1}$; Juliana Marigo ${ }^{1}$; Ana Carolina Ewbank ${ }^{1}$; \\ Cíntia Maria Favero ${ }^{1}$; Juliana Mariotti Guerra ${ }^{3}$; Rodrigo Albergaria Réssio ${ }^{3}$; Marta Jussara Cremer ${ }^{4}$; \\ Fernando Esperón ${ }^{5}$; José Luiz Catão-Dias ${ }^{1}$

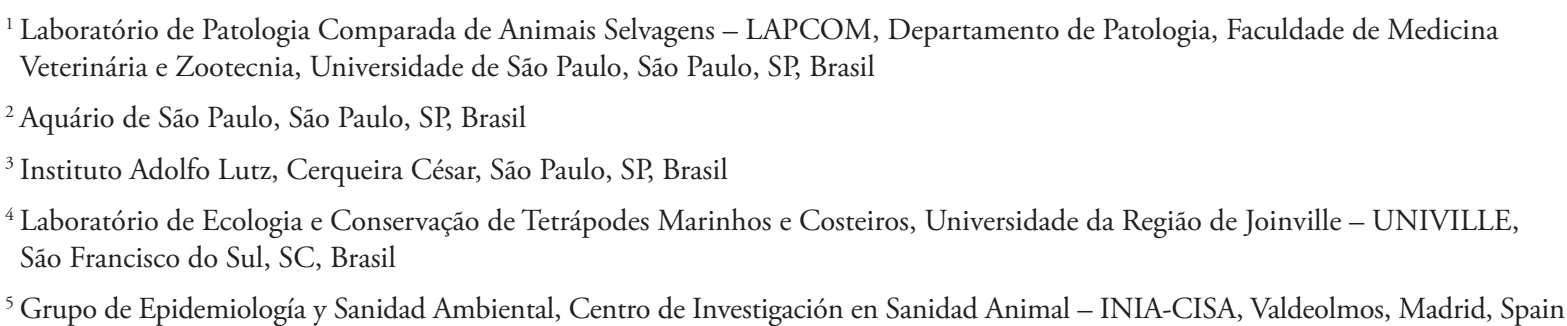

Received November 21, 2018

Accepted March 28, 2019

\begin{abstract}
A juvenile subantarctic fur seal (Arctocephalus tropicalis) found dead in Santa Catarina state, southern Brazil, presented with disseminated verminous pneumonia due to Parafilaroides sp. A concomitant infection with two different gammaherpesviruses was identified by PCR in different tissues; one of them possibly a novel species (tentatively named Otariid herpesvirus 7). Sarcocystis sp. DNA was identified molecularly in skeletal muscle samples with intrasarcoplasmic bradyzoites and no apparent tissue response. All analyzed samples (mandibular, laryngeal, tracheal, and mesenteric lymph nodes, and lung) were PCR-negative for Brucella spp. The most likely cause of death was severe pulmonary parafilaroidiasis. The pathogenic role of the gammaherpesviruses in several of the tissues was not evident. This study describes the pathogenicity of Parafilaroides sp. in a subantarctic fur seal, widens the host range of herpesvirus in pinnipeds, and reports the first molecular identification of Sarcocystis sp. in this species.
\end{abstract}

Keywords: Herpesvirus, Parafilaroides sp., pneumonia, pinniped, protozoan infection, stranding.

\section{Resumo}

Um lobo-marinho-subantártico (Arctocephalus tropicalis) juvenil foi achado morto no Estado de Santa Catarina, sul do Brasil, apresentando pneumonia parasitária disseminada por Parafilaroides sp. Infecção concomitante por dois gammaherpesvírus diferentes foi identificada pela PCR em diversos tecidos, um desses herpesvírus possivelmente uma nova espécie (denominada provisoriamente Otariid herpesvirus 7). DNA de Sarcocystis sp. foi identificado molecularmente em amostras de músculo esquelético que apresentavam bradizoítos intra-sarcoplasmáticos sem aparente resposta tecidual. Todas as amostras analisadas (linfonodo mandibular, laríngeo, traqueal e mesentérico, e pulmão) pela PCR para Brucella spp. foram negativas. A causa mais provável da morte do animal foi parafilaroidose pulmonar severa. O papel patogénico dos gammaherpesvírus em vários tecidos não foi evidente. Este estudo descreve a patogenicidade de Parafilaroides sp. em um lobo-marinho-subantártico, amplia a variedade de hospedeiros de herpesvírus em pinípedes e reporta a primeira identificação molecular de Sarcocystis sp. para essa espécie.

Palavras-chave: Herpesvírus, Parafilaroides sp., pneumonia, pinípede, infecção por protozoários, encalhe.

\footnotetext{
*Corresponding author: Laura Reisfeld. Departamento de Patologia,

Faculdade de Medicina Veterinária e Zootecnia, Universidade de São Paulo,

Av. Orlando Marques de Paiva, 87, Butantã, CEP 05508-270, São Paulo, SP,

Brasil.e-mail: lauravet@aquariodesaopaulo.com.br
} 
Parasitic respiratory disease by nematodes, including Otostrongylus circumlitus (Metastrongyloidea: Crenosomatidae) and Parafilaroides spp. (Metastrongyloidea: Filaroididae), are significant causes of morbidity and mortality in free-ranging pinnipeds (DAILEY, 2001; SIEBERT et al., 2007); however, there is limited information concerning Parafilaroides infection and associated pathology in South American pinnipeds (JACOBUS et al., 2016).

To date, six gammaherpesvirus species have been described in Otariidae (SACRISTÁN et al., 2018), associated with different clinicopathological presentations, from asymptomatic infections to neoplasia (e.g., urogenital carcinomas) (LIPSCOMB et al., 2000; CORTÉS-HINOJOSA et al., 2016). Nevertheless, only one report describes herpesvirus infection in free-ranging pinnipeds from South America, a South American fur seal (Arctocephalus australis) with ulcerative skin lesions (SACRISTÁN et al., 2018). Herein fatal Parafilaroides sp. pneumonia in a subantarctic fur seal (Arctocephalus tropicalis) coinfected with two different gammaherpesvirusesand Sarcocystis sp. is described.

A $157 \mathrm{~cm}$-long cachectic juvenile male subantarctic fur seal was found in a state of moderate decomposition (code 3) (GERACI \& LOUNSBURY, 2005) in Praia do Forte, São Francisco do Sul, Santa Catarina, Brazil (2614'36” S, 48³8'17” W), on 19 August 2013. The carcass was stored frozen at $-20^{\circ} \mathrm{C}$. After thawing at room temperature for several hours, representative tissue samples of the main organs were collected during a complete standard necropsy (GERACI \& LOUNSBURY, 2005) and preserved in $10 \%$ neutral buffered formalin or frozen at $-80{ }^{\circ} \mathrm{C}$. Formalin-fixed samples were routinely processed, sectioned at $5 \mu \mathrm{m}$ and stained with hematoxylin and eosin ( $\mathrm{H} \& \mathrm{E})$ for histopathologic examination.

Samples of cerebral cortex, cerebellum, spinal cord, trachea, lung, heart, esophagus, thyroid, liver, spleen, pancreas, adrenal gland, kidney, testicle, lymph nodes (mandibular, laryngeal, tracheal, mesenteric), urinary bladder, and skeletal muscle were evaluated by universal PCR assays to partially amplify the herpesviral DNA polymerase and glycoprotein B genes (VANDEVANTER et al., 1996; EHLERS et al., 2008).

Samples of mandibular, laryngeal, tracheal, and mesenteric lymph nodes, and lung samples were tested for Brucella spp. infection by conventional PCR with primers B4 and B5 targeting a fragment of the $b c s p 31$ gene (BAILY et al., 1992). Skeletal muscle was tested for Sarcocystis spp. using a nested PCR technique designed to detect DNA fragments of the Toxoplasmatinae ITS-1 region (SOARES et al., 2011), that also amplifies Sarcocystis sp. (C. Sacristán personal observation). Appropriate positive and negative controls (DNA from a previously herpesvirus-positive South American fur seal skin sample, B. abortus (vaccine RB-51) and an isolate of Sarcocystis neurona were used as positive controls for herpesvirus, Brucella spp. and Sarcocystis spp., respectively, while Diethylpyrocarbonate (DPEC) water was used as negative control) were selected for all PCR analyses. Positive amplicons were confirmed by direct DNA sequencing.

The obtained forward and reverse sequences were assembled using ClustalW alignment and compared with those available in GenBank/EMBL/DDBJ database using online BLASTn search (http://www.ncbi.nlm.nih.gov/blast). After the alignment of our sequences and those more similar from GenBank/EMBL/DDBJ database using ClustalW, nucleotide and amino acid identities were calculated based on the p-distance. A 1,000 bootstrap replicates maximum likelihood phylogenetic tree of amino acid sequences was generated for herpesviruses based on the MUSCLE alignment of herpesviral glycoprotein B gene from the novel sequences, and sequences published from other pinnipeds, and selected alpha-,

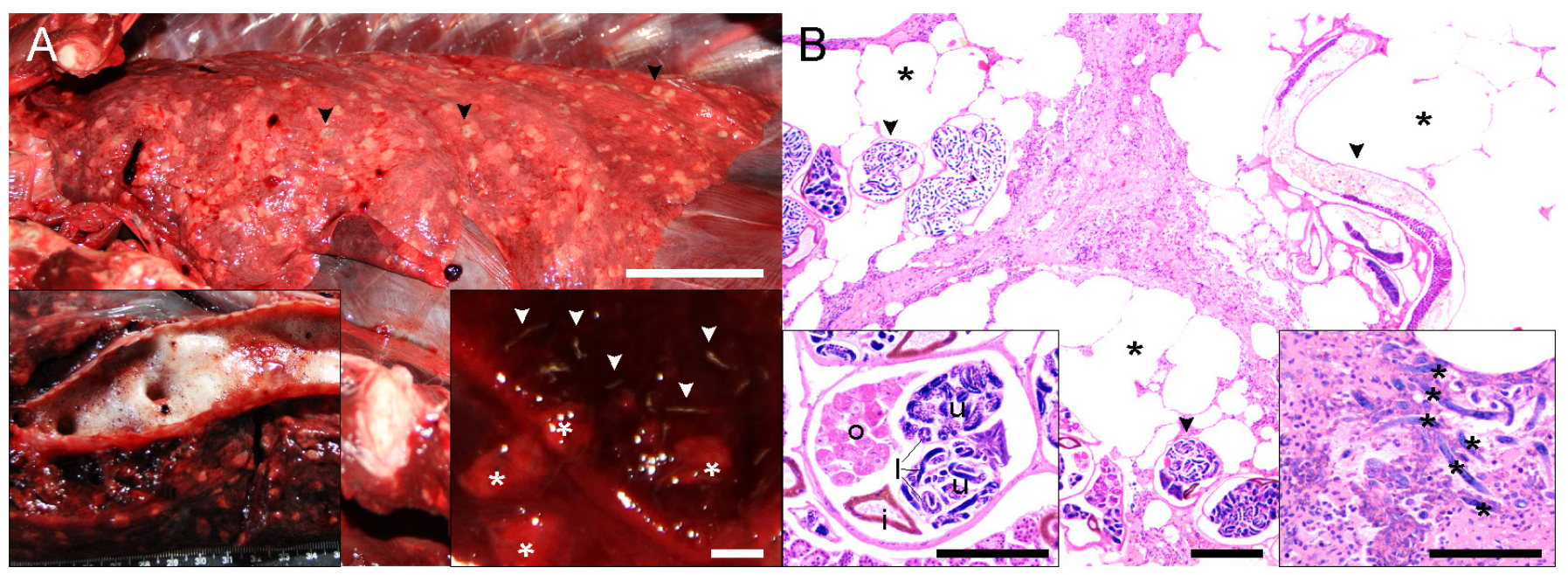

Figure 1. Subantarctic fur seal (Arctocephalus tropicalis) with pulmonary parafilaroidiasis. (A) Disseminated pale pink to white, crepitant and slightly raised nodules with occasional dark foci (arrows) are throughout the pleural surface of the left lung lobes. Also, the lung lobes are incompletely collapsed and display rib impressions. The left thoracic wall has been removed. Bar $=10 \mathrm{~cm}$. Left inset: the left main bronchus and primary bronchi are filled with frothy fluid (pulmonary edema). Scale in $\mathrm{cm}$. Right inset: close view of subpleural and intraparenchymal lung nodules (asterisks) upon section. Multiple nematodes (arrows) extruded from lung nodules upon pressure. Bar $=5 \mathrm{~mm}$. (B) Three foci of alveolar emphysema (asterisks) contain thinned, distended and distorted alveolar walls along with Parafilaroides sp. adults (arrows) and are delineated by chronically inflamed and mildly fibrotic interstitium. Hematoxylin and Eosin (H\&E) stain. Bar $=200 \mu \mathrm{m}$. Left inset: cross section of adult female Parafilaroides sp. H\&E stain. Bar $=100 \mu \mathrm{m}$. Right inset: numerous intraalveolar nematode larvae (asterisks) targeted by inflammatory exudate admixed with karyorhectic cell debris, edema and fibrin. H\&E stain. Bar = $50 \mu \mathrm{m}$. i, intestine; l, larva; o, ova; u, uterus. 
beta-, and gammaherpesviruses sequences identified in other taxa, available on GenBank. All programs were displayed in MEGA software, version 7 (KUMAR et al., 2016).

Grossly, the main findings were lung edema, disseminated parenchymal and subpleural lung nodules containing Parafilaroides sp. nematodes (Figura 1a), and skeletal muscle wasting. Additional findings included: a complete fracture of the inferior left canine, unidentified merocercoids compatible with Phyllobothrium spp. in the perigenital blubber, left thyroid lobe enlargement, unidentified nematodes in bronchi, ulcerative pyloric gastritis with presence of plastic debris and small numbers of Anisakids (likely to be a species of Contracaecum (Nematoda) in the stomach, and urinary calculi in the bladder.

Microscopically, the lung had numerous, variably large foci of alveolar emphysema with ruptured walls intercalated with atelectic, congested and edematous areas (Figura 1b), as well as mild to moderate, chronic lymphocytic bronchointerstitial pneumonia with fibrosis and remodeling. Emphysematous foci often had numerous adult and larval nematodes morphologically compatible with Parafilaroides sp. and little inflammatory response (Inset in Figura 1b) (GARNER et al., 1997). By contrast, there was moderate, focal inflammatory exudate in areas with L1 larvae (Inset in Figure 1b). Additional microscopic findings were: mild, multifocal, granulocytic dermatitis with mild ballooning degeneration, chronic lymphocytic tracheitis, mild acute skeletal muscle and heart rhabdomyolysis, necrohemorrhagic pyloric gastritis with submucosal microthrombi and vascular necrosis, and multinodal lymphoid reactive hyperplasia. Intrasarcoplasmic protozoan cysts compatible with Sarcocystis sp. were observed in the longissimus dorsi muscle with no inflammatory reaction.

Two different herpesvirus sequences of $453 \mathrm{bp}$ of glycoprotein B gene were obtained; one from laryngeal lymph node, adrenal gland, heart, liver, and cerebral cortex, and another from skeletal muscle, spleen and lung samples (sequences MH921583 and MH921584, respectively). Herpesviral DNA polymerase PCR produced weak bands, precluding sequencing. Upon comparison, both Subantartic fur seal glycoprotein B gammaherpesvirus sequences presented 85.2\% nucleotide and $93.3 \%$ amino acid identities among them. The gammaherpesvirus sequence MH921583 presented the highest nucleotide and amino acid identities ( $94.7 \%$ and $98.7 \%$, respectively) to the Otariid herpesvirus 5 (OtHV-5, MF496135.1) previously identified in a South American fur seal. The gammaherpesvirus sequence MH921584 had the highest nucleotide identity (85.4\%) to the OtHV-5 (MF496135.1) detected in a South American fur seal, and the highest amino acid identity (94\%) to a harp seal herpesvirus (KP136799.1). The amino acid phylogram indicated that our two novel herpesvirus sequences clustered with other pinniped gammaherpesvirus sequences from the genus Percavirus (Figure 2).

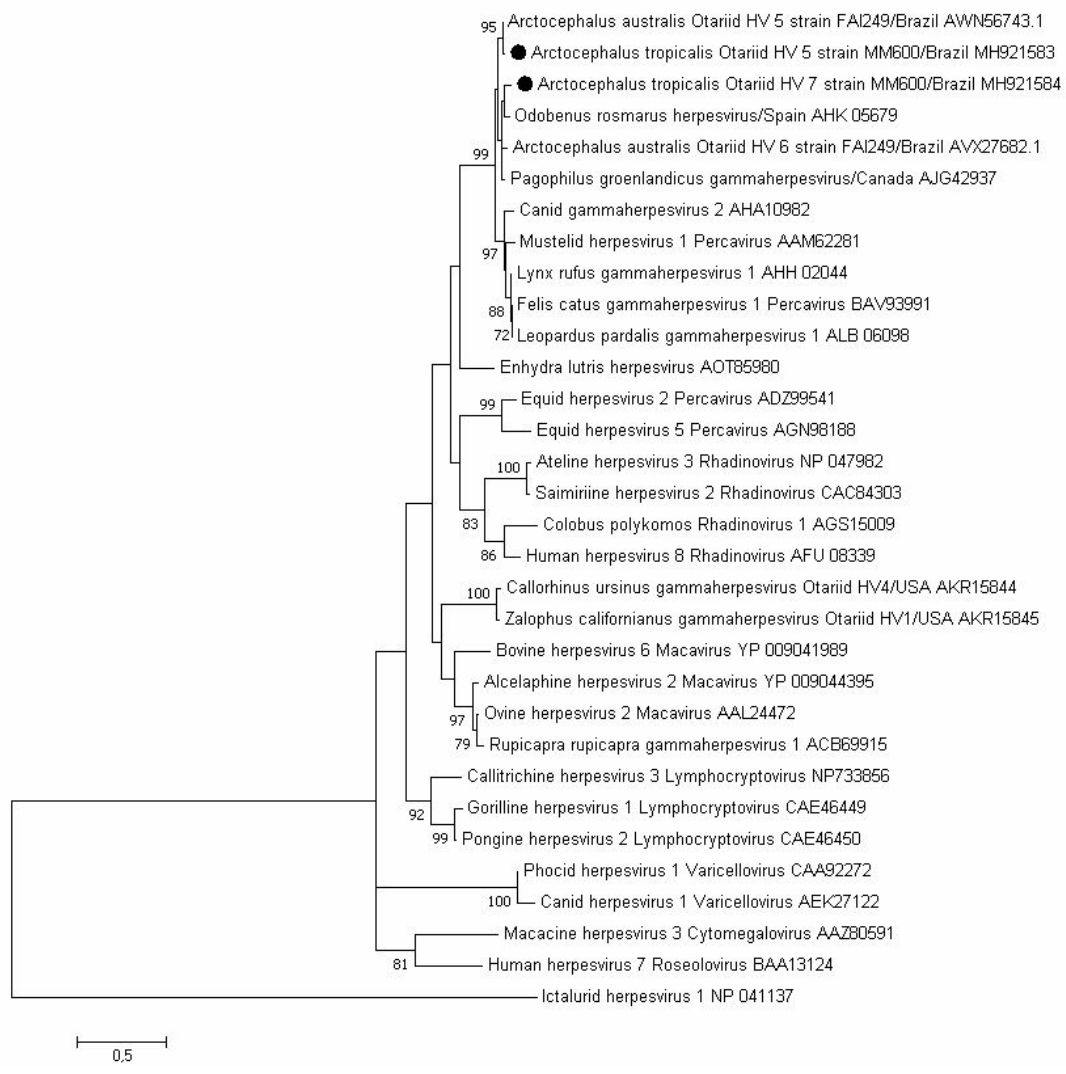

Figure 2. Phylogenetic analysis based on the alignment 151 deduced amino acid sequences of the herpesviral DNA glycoprotein B sequences found in the Subantartic fur seal (Arctocephalus tropicalis) (circle), 29 alpha-, beta- and gammaherpesvirus sequences obtained from GenBank. An Ictalurid herpesvirus 1 sequence was included as outgroup (GenBank accession no. NP_041137). The phylogenetic analysis was performed in MEGA7 (KUMAR et al., 2016) using the maximum likelihood method. The reliability of the tree was tested by bootstrap analyses with 1000 bootstrap replicates. Bootstrap values lower than 70\% were omitted. Taxon names are presented as herpesvirus species, genus (when assigned), country of origin (for herpesvirus sequences detected in pinnipeds) and accession number. 
No positive amplification of Brucella spp. was observed. From muscle sample, one novel ITS-1 region sequence (882 bp, excluding primers) was obtained, most similar to Sarcocystis sp., submitted to GenBank under accession number MH918015. The obtained ITS-1 sequence had the highest nucleotide identity (99.9\%) with Sarcocystis sp. (HQ184185) identified in the muscle of a sperm whale (Physeter macrocephalus) from Washington, USA, although the sperm whale sequence was shorter than our sequence ( 800 vs. $882 \mathrm{bp}$ ). The second highest identity was to a sequence of $S$. canis $(86.4 \%$, DQ176645) obtained from the liver of a captive polar bear (Ursus maritimus) from Alaska, USA, that presented the same length as our sequence.

Herein, fatal pneumonia by Parafilaroides sp. was identified in a cachectic subantarctic fur seal coinfected by two different gammaherpesviruses and Sarcocystis sp. Pulmonary parafilaroidiasis cases by Parafilaroides sp. and P. normani have been reported, respectively, in South American and Antarctic fur seals (Arctocephalus gazella) from Brazil (JACOBUS et al., 2016), and in a subantarctic fur seal from South Africa (DAILEY, 2009). Additionally, thromboembolism associated with verminous pulmonary vasculitis by Parafilaroides decorus has been described in a Guadalupe fur seal (Arctocephalus philippii townsendi) (SEGUEL et al., 2018). Despite these previous reports, the pathology of Parafilaroides spp. is still poorly known. In the present case, while there was mild, chronic bronchointerstial inflammatory response with mild remodeling, the most severe pathogenetic parasitic consequence appeared to involve airflow obstruction and alveolar emphysema with septal distortion and rupture. These findings are in agreement with previous observations of parafilaroidiasis in other pinnipeds, despite some variations among host species (MEASURES, 2001; JACOBUS et al., 2016). Our results suggest that Parafilaroides sp. infection is present along the distribution range of subantarctic fur seals, and that this parasite may be fatal and a significant cause of morbidity in this marine species.

Two gammaherpesvirus sequences were detected, widening the host range of herpesvirus in pinnipeds. No intranuclear inclusion bodies were observed on histopathology, similarly to other reports of herpesvirus infections in pinnipeds (MELERO et al., 2014; SACRISTÁN et al., 2018). According to the International Committee on Taxonomy of Viruses for herpesviruses (DAVISON et al., 2005), the observed nucleotide and amino acid identities suggest the gammaherpesvirus sequence MH921584 could be classified as a novel species, proposed here as Otariid herpesvirus 7, while the other sequence (MH921583) was possibly a different OtHV-5 strain. The pathogenetic role of these gammaherpesviruses was not clear; both were possibly reactivated from latency due to prolonged debilitation of the studied animal, as suggested by the detection of herpesvirus in several organs, but not necessarily associated with clinical disease (GRINDE, 2013).

Based on the detection of highly similar ITS-1 Sarcocystis sp. sequences in muscle samples of pinniped and cetacean species from distant geographical areas (southwestern Atlantic and northeastern Pacific), one could consider the involvement of a possible Sarcocystis species with a marine cycle. Further research is necessary to confirm such hypothesis.

We report a case of fatal pulmonary parafilaroidiasis in a subantarctic fur seal coinfected with two different gammaherpesviruses, one of them possibly a novel species, tentatively named Otariid herpesvirus 7, and Sarcocystis sp. Future studies are warranted to establish the potential impact of these novel herpesvirus sequences, and to identify the Parafilaroides and Sarcocystis species infecting subantarctic fur seals.

\section{Acknowledgements}

The authors thank the staff of UNIVILLE, Sândara Sguario and Jorge Oyakawa at the School of Veterinary Medicine and Animal Science, University of São Paulo, and Elena Neves at the INIA-CISA for their excellent technical support and collaboration.

\section{References}

Baily GG, Krahn JB, Drasar BS, Stoker NG. Detection of Brucella melitensis and Brucella abortus by DNA amplification. J Trop Med Hyg 1992; 95(4): 271-275. PMid:1495123.

Cortés-Hinojosa G, Gulland FMD, DeLong R, Gelatt T, Archer L, Wellehan JFX Jr. A novel gammaherpesvirus in northern fur seals (Callorhinus ursinus) is closely related to the California sea lion (Zalophus californianus) carcinoma associated Otarine herpesvirus-1. J Wildl Dis 2016; 52(1): 88-95. http:// dx.doi.org/10.7589/2015-03-060. PMid:26555110.

Dailey MD. Parasitic diseases. In: Dierauf LA, Gulland FMD. CRC Handbook of marine mammal medicine, 2nd ed. Boca Raton: CRC Press; 2001. p. 357-379. http://dx.doi.org/10.1201/9781420041637.ch18.

Dailey MD. A new species of Parafilaroides (Nematoda: Filaroididae) in three species of fur seals (Carnivora: Otariidae) from the southern hemisphere. J Parasitol 2009; 95(1): 156-159. http://dx.doi.org/10.1645/GE-1521.1. PMid:18652523.

Davison A, Erberle R, Hayward G, McGeoch D, Minson A, Pellet P, et al. Family Herpesviridae. In: Fauquet CM, Mayo MA, Maniloff J, Desselberger U, Ball LA. Virus Taxonomy: Eighth Report of the International Committee on Taxonomy of Viruses. San Diego: Academic Press; 2005. p. 193-212.

Ehlers B, Dural G, Yasmum N, Lembo T, de Thoisy B, Ryser-Degiorgis $\mathrm{MP}$, et al. Novel mammalian herpesviruses and lineages within the Gammaherpesvirinae: Cospeciation and interspecies transfer. JVirol 2008 82(7): 3509-3516. http://dx.doi.org/10.1128/JVI.02646-07. PMid:18216123.

Garner MM, Lambourn DM, Jeffries SJ, Hall PB, Rhyan JC, Ewalt DR, et al. Evidence of Brucella infection in Parafilaroides lungworms in a Pacific harbor seal (Phoca vitulina richardsi). J Vet Diagn Invest 1997; 9(3): 298-303. http://dx.doi.org/10.1177/104063879700900311. PMid:9249169.

Geraci JR, Lounsbury VJ. Marine mammals ashore: a field guide for strandings. 2nd ed. Baltimore: National Aquariumin Baltimore; 2005.

Grinde B. Herpesviruses: latency and reactivation-viral strategies and host response. J Oral Microbiol 2013; 5(1): 22766. http://dx.doi.org/10.3402/ jom.v5i0.22766. PMid:24167660.

Jacobus K, Marigo J, Gastal SB, Taniwaki SA, Ruoppolo V, Catáo-Dias $\mathrm{JL}$, et al. Identification of respiratory and gastrointestinal parasites of three species of pinnipeds (Arctocephalus australis, Arctocephalus gazella, and Otaria flavescens) in southern Brazil. JZoo Wildl Med 2016; 47(1): 132-140. http:// dx.doi.org/10.1638/2015-0090.1. PMid:27010274.

Kumar S, Stecher G, Tamura K. MEGA7: Molecular Evolutionary Genetics Analysis version 7.0 for bigger datasets. Mol Biol Evol 2016; 33(7): 1870 1874. http://dx.doi.org/10.1093/molbev/msw054. PMid:27004904. 
Lipscomb TP, Scott DP, Garber RL, Krafft AE, Tsai MM, Lichy JH, et al. Common metastatic carcinoma of California sea lions (Zalophus californianus): evidence of genital origin and association with novel gammaherpesvirus. Vet Pathol 2000; 37(6): 609-617. http://dx.doi.org/10.1354/vp.37-6-609. PMid:11105950.

Measures LN. Lungworms of marine mammals. In: Samuel WM, Pybus MJ, Kocan AA. Parasitic diseases of wild mammals. 2nd. Ames: Iowa State University Press; 2001. p. 279-300. http://dx.doi.org/10.1002/9780470377000.ch10.

Melero M, García-Párraga M, Corpa JM, Ortega J, Rubio-Guerri C, Crespo $\mathrm{JL}$, et al. First molecular detection and characterization of herpesvirus and poxvirus in a Pacific walrus (Odobenus rosmarus divergens). BMC Vet Res 2014; 10(1): 968. http://dx.doi.org/10.1186/s12917-014-0308-2. PMid:25527906.

Sacristán C, Esperón F, Ewbank AC, Costa-Silva S, Marigo J, Matushima ER, et al. Identification of novel gammaherpesviruses in a South American fur seal (Arctocephalus australis) with ulcerative skin lesions. JWildl Dis 2018; 54(3): 592-596. http://dx.doi.org/10.7589/2017-09-224. PMid:29595382.
Seguel M, Nadler S, Field C, Duignan P. Vasculitis and thrombosis due to the sea lion lungworm, Parafilaroides decorus, in a Guadalupe fur seal (Arctocephalus philippii townsendi). J Wildl Dis 2018; 54(3): 638-641. http://dx.doi.org/10.7589/2017-12-291. PMid:29715062.

Siebert U, Wohlsein P, Lehnert K, Baumgartner W. Pathological findings in harbour seals (Phoca vitulina): 1996-2005. J Comp Pathol 2007; 137(1): 47-58. http://dx.doi.org/10.1016/j.jcpa.2007.04.018. PMid:17629967.

Soares RM, Lopes EG, Keid LB, Sercundes MK, Martins J, Richtzenhain LJ. Identification of Hammondia heydorni oocysts by a heminested-PCR (hnPCR-AP10) based on the H. heydorni RAPD fragment AP10. Vet Parasitol 2011; 175(1-2): 168-172. http://dx.doi.org/10.1016/j.vetpar.2010.09.022. PMid:21030154.

VanDevanter DR, Warrener P, Bennett L, Schultz ER, Coulter S, Garber $\mathrm{RL}$, et al. Detection and analysis of diverse herpesviral species by consensus primer PCR. J Clin Microbiol 1996; 34(7): 1666-1671. PMid:8784566. 